\title{
Dlouhodobé sledování úrovně výkonnostních předpokladů vybraných tenistů
}

\section{Long time pursuit of the performance predispositions level of the select tennis-players}

\author{
${ }^{1}$ Michal Polách, ${ }^{1}$ Jiřŕ Zháněl, ${ }^{2}$ Ondřej Hubáček \\ ${ }^{1}$ Fakulta sportovních studií Masarykovy univerzity, Brno \\ ${ }^{2}$ Fakulta tělesné kultury Univerzity Palackého, Olomouc
}

\begin{abstract}
Abstrakt
Sledování úrovně jednotlivých faktorů neboli výkonnostních předpokladů ve sportu je důležitou součástí tréninkové prípravy sportovce. Článek pojednává o výsledcích výzkumu diagnostiky výkonnostních předpokladů vybrané skupiny tenistio.

V rámci výzkumu jsme nejprve provedli výběr hráčů podle kritéria četnosti účasti na testování, dalším kritériem se stala výkonnostní úroveñ, které dosáhli - žebřičkové umistění. V dalši fázi jsme analyzovali jednotlivé testové výsledky hráču z dlouhodobého hlediska. Posledním krokem bylo posouzení vztahu mezi věkem, výsledky testové baterie a herní výkonností. Z dưvodu malého počtu měrení a komplexnosti sportovního výkonu v tenise jsme neočekávali přiliš těsnou vazbu (korelaci) jednotlivých proměnných.

Došli jsme k závěrům, že u všech sledovaných hráču byla zaznamenána prevážně vysoká úroveň kondičněkoordinačnich (motorických) výkonnostních předpokladi̊, což koresponduje s jejich vysokou tenisovou výkonností a žebřičkovým umistěním, přestože to nebylo prokázáno statisticky.
\end{abstract}

\section{Abstract:}

Monitoring the level of individual factors or performance predispositions is an essential part of athlete's training process. The article discusses the results of the diagnostic performance predispositions research of the selected group of tennis players.

In the research, we first made a selection of players according to the criterion of the frequency of participation in testing and the other criterion was the performance level, ranking, they reached. In the next phase, we analyzed the individual test results of the players in the long-term perspective. The final step was to assess the relationship between age, the results of the test battery and game performance. Due to the small number of measurements and the complexity of sport performance in tennis we did not expect very tight dependence (correlation) of individual variables.

We came to the conclusion that by all observed players a high level of motor performance predisposition were recorded which corresponds with their high performance in tennis and ranking, although statistical dependence was not proven.

Klíčová slova: diagnostika, longitudinální výzkum, retrospektivní studie, tenis, testová baterie, výkonnostní predpoklady

Key words: diagnostics, longitudinal research, performance predispositions, retrospective study, tennis, test battery

\section{ÚVOD}

Problematika struktury sportovního výkonu je v oblasti sportovních věd dlouhodobě výzkumně řešena. Za základní faktory sportovního výkonu jsou považovány faktory tělesné konstituce (označované také jako 
faktory somatické, resp. biologické), faktory kondice (označované také jako faktory motorické; mezi ně bývají řazeny i faktory koordinace), faktory techniky, faktory taktiky, faktory psychické, někdy označované jako faktory osobnostní (Dovalil et al., 2009; Grosser \& Zintl, 1994; Moravec, Kampmiller, Vanderka, \& Laczo, 2004; Schnabel, Harre, Krug, \& Borde, 2003). V jednotlivých druzích sportu je důležité identifikovat ty faktory, které sportovní výkon významně determinují, resp. ovlivňují - bývají označovány jako sportovně-specifické faktory (předpoklady).

Diagnostika sportovně-specifických faktorů ovlivňujících herní výkon $\mathrm{v}$ tenise je nezbytnou součástí tréninkového procesu. Tato diagnostika je dlouhodobě předmětem celé řady výzkumných prací, což je - mimo jiné - i odrazem mediálního a komerciálního boomu tohoto sportu od konce 70. let minulého století. Zvláště spolupráce tenisových odborníků $\mathrm{s}$ vědeckovýzkumnými pracovníky z akademického prostředí univerzit přinesla - zejména v zahraniční - vznik četných odborných publikací (Zháněl, 2005). Výsledky výzkumů ukazují, že vazba mezi úrovní sportovně-specifických předpokladů (zejména motorických schopností) a sportovní výkonností je vyšší u jednoduchých, individuálních, tzv. uzavřených druhů sportů (např. lehkoatletické disciplíny), zatímco v tzv. otevřených (zejména kolektivních) sportech jsou tyto vazby velmi nízké (Roth \& Willimczik, 1999). Nejsložitější problémy vznikají při diagnostice výkonnostních předpokladů ve sportovních hrách, nebot' množství, různost a vzájemná provázanost faktorů ovlivňujících sportovní výkon ve hrách je nepoměrně větší než např. v atletice, cyklistice či lyžování atd. (Wohlmann, 1996).

Je tedy zřejmé, že jednotlivé sporty vyžadují různou úroveň těchto předpokladů s ohledem na strukturu požadavku. V návaznosti na obecné členění faktorů sportovního výkonu lze v tenise zmíněné sportovněspecifické faktory rozdělit na faktory limitující výkon, resp. ovlivňující výkon (Deutscher Tennis Bund, 1996). Faktory limitující výkon jsou považovány za velmi důležité a málo kompenzovatelné; faktory ovlivňující výkon jsou sice důležité, ale jsou do jisté míry kompenzovatelné jinými přednostmi (Obrázek 1).

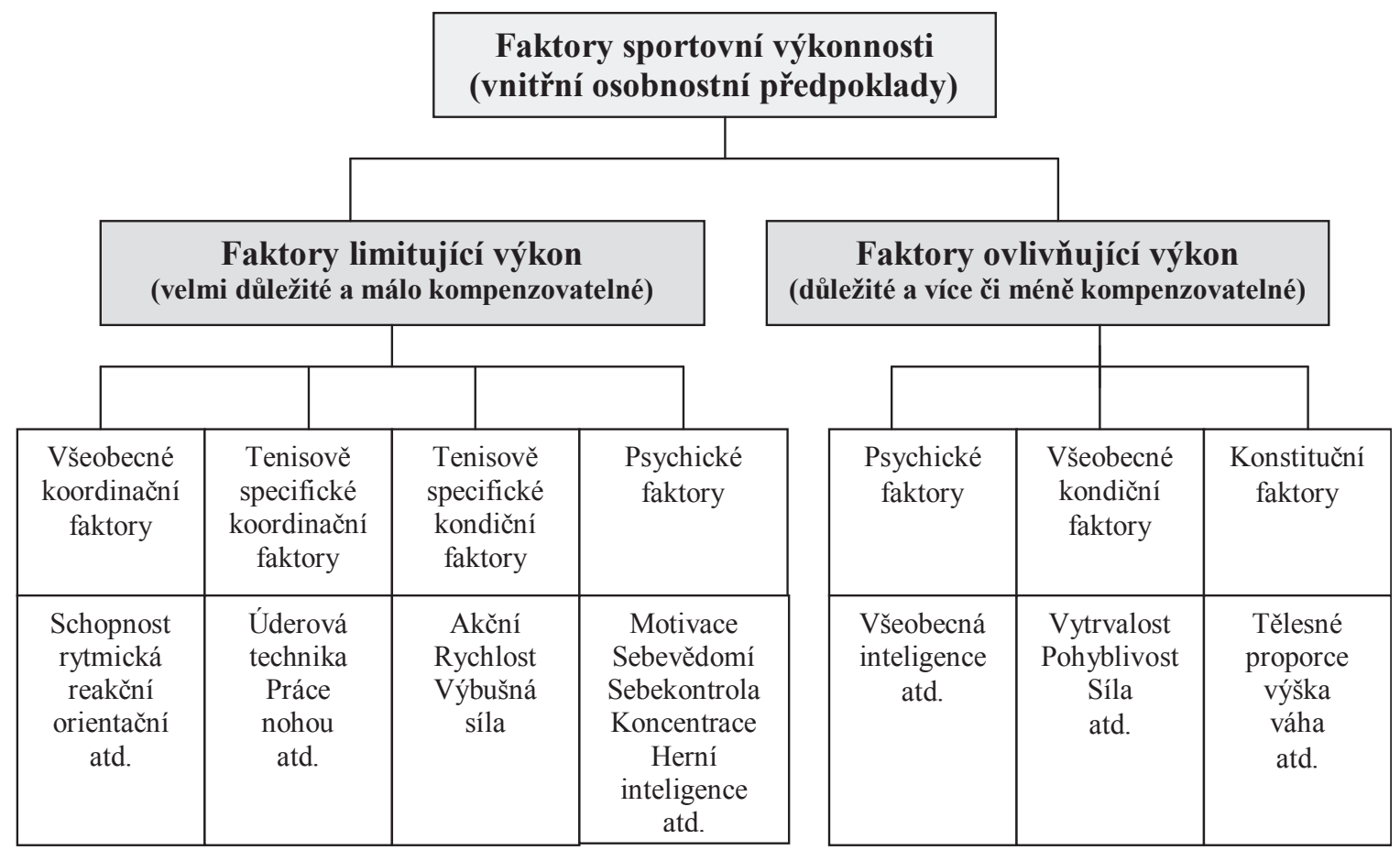

Obr. 1: Přehled faktorů sportovního výkonu v tenise (Tennis-Lehrplan, 1996, upraveno)

Vzhledem $\mathrm{k}$ tomu, že vývoj světového tenisu směřuje stále více $\mathrm{k}$ silnějšímu, rychlejšímu a celkově kondičně náročnějšímu stylu hry, má v současné době stále větší význam systematická, pravidelná a dlouhodobá diagnostika (Černošek, Zháněl, Psalman, \& Zvonař, 2012; Perič, Suchý et al., 2010; Reid, Quinn, \& Crespo, 2003; Zháněl, Černošek, Martinovský, \& Agricola, 2008). Výzkum vycházel z principů tzv. retrospektivní teorie, která předpokládá, že sportovci úspěšní v dospělosti disponovali již v mládí vysokou úrovní určitých 
specifických výkonnostních předpokladů (Hohmann, 2010). Tato teorie představuje jeden z možných př́stupů, jak se pokusit o identifikaci talentu ve sportu.

Crespo a McInerney (2006) uvádějí, že programy identifikace talentu začaly v zemích bývalého „východního bloku“ v období let 1960-70 a stály za úspěchy těchto států na olympijských hrách. Současná sportovní věda se snaží determinovat ty faktory, které z talentovaných mladých hráčủ udělají v dospělosti „top hráče“. Dále autoři uvádějí, že obecně slouží k identifikaci talentů dva základní modely. Prvním je model přirozeného výběru, kdy se hráči postupně zdokonalují ve svých hráčských dovednostech a snaží se hrát stále významnější turnaje, až se z nich postupně stávají profesionálové. Hlavním kritériem je „dobré oko trenéra“ a také výsledkové úspěchy hráčů. Druhým je vědecky založený model, kdy je snahou, aby v tomto procesu pomohly vědecké poznatky. Přitom je kladen důraz na poznatky antropometrie, fyziologie nebo psychologie. Zároveň se zde výsledky výzkumu používají k vytváření testových baterií. Dlouhodobý hráčský vývoj je komplexní proces, který by měl zahrnovat identifikaci a výběr talentovaných hráčů na všech úrovních. Je třeba, aby přitom spolupracovali trenéři a sportovní vědci. Programy pro talentované hráče by však neměly diskriminovat ty méně nadané, ale naopak pomáhat trenérům a národním asociacím navrhovat školicí a soutěžní programy pro všechny hráče. Grosser a Schönborn (2008) uvádějí čtyři kroky při výběru talentů v tenise: 1. rozpoznání pohybově nadaných dětí na základě pozorování, 2. diagnostika úrovně všeobecných motorických schopností, 3. základní lékařská a sportovní diagnostika (po 2-6 měsících), 4. průběžné využívání záznamu (checklist) pro komplexní posouzení osobnostních, somatických, psychických, motorických předpokladů a vnějších vlivů. Unierzyski (2006) uvádí, že programy identifikace talentu by měly mít dlouhodobý charakter s podporou sportovních vědců, ale s dominantní rolí trenéra. Je prokázáno, že výsledky v juniorském věku nemohou predikovat, že hráč bude mít úspěchy také v profesionálním tenise. Identifikace talentu nesmí být založena pouze na výsledcích, ačkoli je třeba, aby hráč v každé věkové kategorii dosáhl určitě úrovně. Autor dále uvádí, že ideální pro testování talentu jsou období 10-11 a 15-16 let, protože právě v tomto období dochází k největším změnám v úrovni pohybu (pohybových schopností). Např́klad v období do 10 let by měl být kladen důraz na testování motorických schopností a tenisově- specifických dovedností. V období od 12 let je doporučováno testovat především specifický rozvoj techniky a taktiky. Obecně můžeme konstatovat, že hledání tenisových talentů je v dnešní době (stejně jako v jiných sportech) spíše náborem nežli výběrem, navíc s nejistým výsledkem. Výběr talentů předpokládá ,....analyzovat $\mathrm{s}$ pomocí praktických a ... sportovně vědeckých výzkumných metod všeobecné motorické a sportovně-specifické složky nadání, a z toho stanovit opatrné prognózy“ (Grosser \& Schönborn, 2008, 146). Vzhledem k tomu, že v tenise je možno se účastnit oficiálních turnajů až od 10 let (v rámci projektu „minitenis“ a „babytenis“ hrají také děti od 6 let turnaje, nejsou však sestavovány celostátní žebříčky), začínají děti s tenisem kolem 6.-8.roku věku (řada dětí ovšem začíná s tenisem již mezi 4.-6. rokem).

Pro diagnostiku výkonnostních předpokladů mladých hráčů a hráček se využívají různé diagnostické metody, např. testové baterie, resp. testové profily, které umožňují sledování více faktorů, zejména je však kladena pozornost na faktory somatické a motorické. Obecně jakýkoli motorický test představuje standardizovaný postup, jehož obsahem je pohybová činnost a výsledkem číselné vyjádření průběhu či výsledku této činnosti (Zháněl, 2005). Wohlmann (1996) uvádí, že v průběhu let 1935-1985 bylo v USA a střední Evropě vyvinuto celkem třicet jednotlivých testů (7) a testových baterií (23) zaměřených na tenisově-specifické motorické schopnosti a dovednosti, přičemž 25,3 \% testových položek bylo zaměřeno na kondici, 6,3 \% na koordinaci, $43,7 \%$ na tenisově-specifické dovednosti a jiný obsah mělo $24,7 \%$ testů. Jak dokumentuje výše uvedený přehled, snaha o diagnostiku úrovně výkonnostních předpokladů v tenise má již sedmdesátiletou tradici.

Výzkumným záměrem bylo analyzovat výsledky získané $\mathrm{v}$ rámci dlouhodobého sledování úrovně výkonnostních předpokladů záměrně vybraných tenistů. Cílem výzkumu bylo (1) posouzení vztahu mezi úrovní motorických výkonnostních předpokladů (charakterizovaných celkovým bodovým skóre dosaženým v testové baterii) a herní výkonností (charakterizované žebříčkovým umístěním) vybraných elitních tenistů v průběhu dlouhodobého sledování, (2) zjištění úrovně motorických předpokladů jednotlivých hráčů ve sledovaném období. 


\section{METODIKA}

Z hlediska výzkumné metodologie (Hendl \& Blahuš, 2012) se jednalo o typy výzkumu „status“, kdy jsou zjišstovány charakteristiky specifikované skupiny (úroveň výkonnostních předpokladů), dále o „př́padovou studii“ s prvky korelační studie zaměřenou na vývoj somatických a motorických výkonnostních předpokladů mladých tenistů a o „vývojovou studii“ zkoumající změny úrovně výkonnostních předpokladů v čase. Výzkumná data byla získána při testování tenistů pomocí testové baterie TENDIAG1 v letech 1998-2005 (Zháněl, Balaš, Trčka, \& Shejbal, 2000) dvakrát ročně (duben, ř́ijen) zaškolenými osobami, s využitím stále stejných testovacích nástrojů, př́strojů a pomůcek. Rovněž bylo zachováváno stejné pořadí testů, bylo dbáno na dostatečné rozcvičení a zaškolení testovaných osob. Navíc se v průběhu testování ukázalo, že provádění většiny testů př́mo na tenisovém kurtu se jeví jako výhodné z toho důvodu, že jde o prostředí hráčům důvěrně známé z každodenních tréninků a zápasů, a navozuje u nich pozitivní př́stup.

Při průměrném hodnocení výsledků jsme došli k závěru, že se nám podařilo navýšit svalovou hmotu trupu z 36,6 kg na 37,8 kg. Pravou horní končetinu jsme zlepšili a vyšly nám statisticky významné hodnoty $(\mathrm{P}<$ 0,005 , Tabulka 3 ). Levou horní končetinu jsme zlepšili a statisticky významné hodnoty nám vykázaly $\mathrm{P}<=0,02$ (Tabulka 4). U pravé dolní končetiny jsme zaznamenali zlepšení, ale nedošlo ke staticky významnému zlepšení (Tabulka 6). Ke stejným výsledkům jsme došli i u dolní levé končetiny (Tabulka 7).

Tabulka 1: Testová baterie TENDIAG 1 (Zháněl et al., 2000)

\begin{tabular}{||c|c||}
\hline \multicolumn{1}{|c|}{ TESTOVÁ BATERIE TENDIAG1 } & JEDNOTKA \\
\hline I. OBLAST TĚLESNÝCH PŘEDPOKLADŮ & \\
\hline 1. Tělesná výška (a hmotnost) & {$[\mathrm{m}][\mathrm{kg}]$} \\
\hline 2. Body Mass Index & {$[\mathrm{index}]$} \\
\hline 3. Pohyblivost ramenních kloubů & {$[\mathrm{index}]$} \\
\hline II. OBLAST KONDIČNíCH SCHOPNOSTÍ & \\
\hline 4. Síla herní ruky & {$[\mathrm{kp}]$} \\
\hline 5. Rychlost běžecká & {$[\mathrm{s}]$} \\
\hline 6. Vytrvalost střednědobá & {$[\mathrm{s}]$} \\
\hline III. OBLAST KOORDINAČNíCH SCHOPNOSTÍ & \\
\hline 7. Rychlost reakce rukou (na vizuální podnět) & {$[\mathrm{s}]$} \\
\hline 8. Rychlost reakce nohou (na vizuální podnět) & {$[\mathrm{s}]$} \\
\hline 9. Pohyblivost trupu & {$[\mathrm{počet]}$} \\
\hline
\end{tabular}

Testy z oblasti tělesných předpokladů mají pouze informativní charakter. Jednotlivé motorické testy (oblast kondičních a koordinačních schopností) jsou hodnoceny na třístupňové škále 0-2 body, ze šesti testů je tedy možno získat $0-12$ bodů. Výsledky testové baterie jsou hráčům a trenérům prezentovány v grafické (Obrázek 2) a numerické podobě (tabulky). 


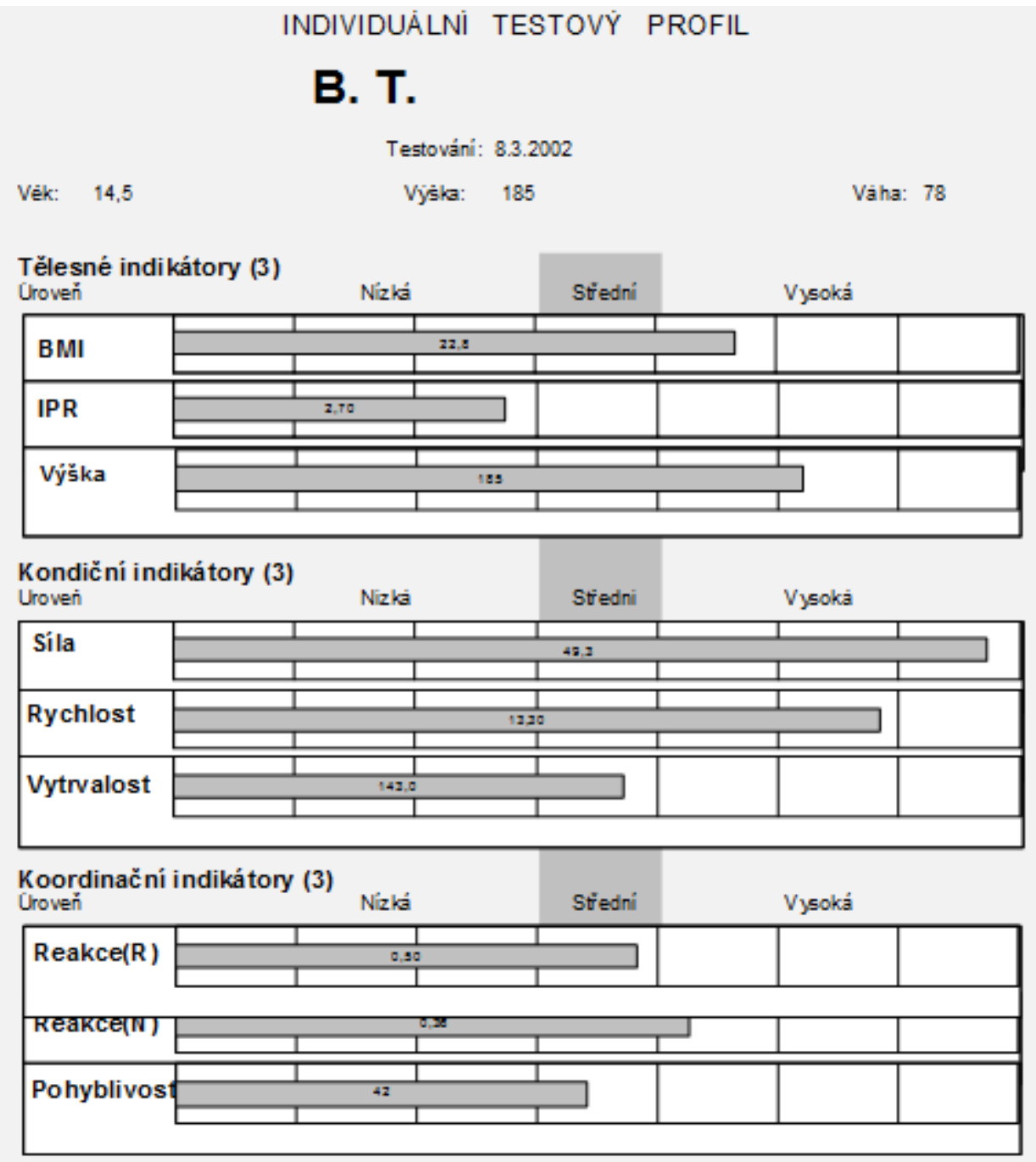

Celková úroveň kondičně-koordinačních předpokladủ

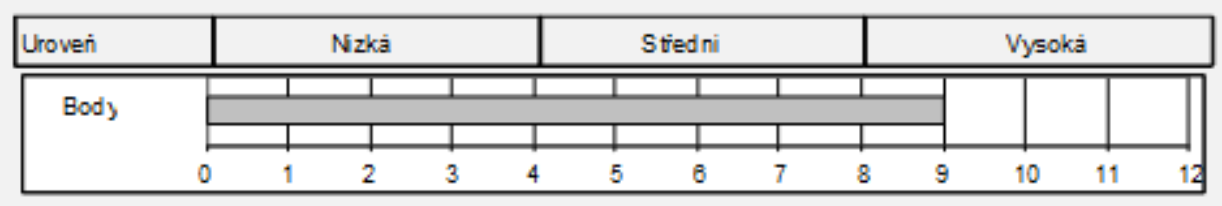

Obr. 2: Př́lklad individuálního testového profilu hráče B. T.

Záměrný výběr hráčů byl proveden na základě těchto kritérií: (1) v žákovském věku patřili mezi prvních 10 v celostátním žebříčku, (2) absolvovali ve sledovaném období minimálně 9 testování. Dle výše uvedených kritérií byli ze souboru tenistů testovaných v letech 1998-2005 (n=623) záměrně vybráni tito hráči $(n=6)$ BT (12), KM (10), LD (14), ML (11), NM (14), RM (9), číslo v závorce označuje počet absolvovaných testování. Výsledky byly zpracovány pomocí adekvátních statistických metod (výpočet základních statistických charakteristik, korelační analýza) s využitím softwaru Excel a STATISTICA. 


\section{Výsledky a diskuze}

Jako příklad způsobu výběru pomocí prvního kritéria uvádíme žebříčkové umístění hráče BT na oficiálních žebříčcích Českého tenisového svazu v letech 1998-2005.

Tabulka 2: Přehled žebřičkového umistění hráče BT v letech 1998-2005

\begin{tabular}{|c|c|c|c|c|c|c|c|c|}
\hline Jméno & CŽ 1998 & CŽ 1999 & CŽ 2000 & CŽ 2001 & CŽ 2002 & CŽ 2003 & CŽ 2004 & CŽ 2005 \\
\hline BT & 8. (SŽ) & 1. (SŽ) & 15. (D) & 1. (D) & 1. (D) & 1. (D) & 2. (M) & 3. (M) \\
\hline
\end{tabular}

Vysvětlivky: CŽ - celostátní žebř́čcek, $M Z ̌$ - mladši žáci, SŽ - staršǐ žáci, D-dorostenci, $M$ - muži

Př́kladem výběru pomocí druhého kritéria je počet testování absolvovaných hráčem LD v letech 1998-2005 (Tabulka 3).

Tabulka 3: Přehled absolvovaných testováni hráče L. D. v letech 1998-2005

\begin{tabular}{|c|c|c|c|c|c|c|c|c|c|}
\hline Jméno & 1998 & 1999 & 2000 & 2001 & 2002 & 2003 & 2004 & 2005 & $\sum$ \\
\hline LD & $1 \mathrm{x}$ & $2 \mathrm{x}$ & $2 \mathrm{x}$ & $2 \mathrm{x}$ & $2 \mathrm{x}$ & $2 \mathrm{x}$ & $2 \mathrm{x}$ & $1 \mathrm{x}$ & 14 \\
\hline
\end{tabular}

V další fázi byla provedena podrobná analýza jednotlivých testových výsledků hráčů získaných v průběhu dlouhodobého sledování. Jako př́klad uvádíme přehled testových výsledků hráče BT (Tabulka 4).

Tabulka 4: Přehled testových výsledki̊ hráče BT v letech $1998-2005$

\begin{tabular}{|c|c|c|c|c|c|c|c|c|c|c|c|c|c|c|}
\hline Jméno & Věk & Výška & Váha & $\mathrm{BMI}$ & IPR & & $\mathrm{SH}$ & RB & $\mathrm{V}$ & $\mathrm{PT}$ & RRR & RRN & ŽP & STB \\
\hline $\mathrm{BT}$ & $\ldots$ & $\ldots$ & $\ldots$ & $\ldots$ & $\ldots$ & & $\ldots$ & $\ldots$ & $\ldots$ & $\ldots$ & $\ldots$ & $\ldots$ & $\ldots$ & $\ldots$ \\
\hline $\mathrm{BT}$ & 13,1 & 171,0 & 61,0 & 20,9 & 2,7 & & 33,2 & 14,2 & 143,8 & 42 & 0,42 & 0,34 & 8 & 10 \\
\hline $\mathrm{BT}$ & $\ldots$ & $\ldots$ & $\ldots$ & $\ldots$ & $\ldots$ & & $\ldots$ & $\ldots$ & $\ldots$ & $\ldots$ & .. & .. & $\ldots$ & \\
\hline
\end{tabular}

Vysvěttivky: BMI - body mass index, IPR - index pohyblivosti v ramennich kloubech,

$R$ - herní ruka (P/L pravá/levá), SH - silla herní ruky, RB - rychlost běžecká,

$V$-vytrvalost, $P T$ - pohyblivost trupu, RRR-rychlost reakce ruka, RRN-rychlost reakce noha, ŽP-žebríčkové pořadí, STB - skóre testové bateri

Pro řešení prvního výzkumného cíle (posouzení vztahu mezi úrovní motorických výkonnostních předpokladů a herní výkonností) byla u jednotlivých hráčů vypočítána korelace mezi celkovým bodovým skóre dosaženým $\mathrm{v}$ testové baterii (nezávisle proměnná $\mathrm{x}$ ) a žebřičkovým umístěním (závisle proměnná $\mathrm{y}$ ). $\mathrm{Z}$ důvodu malého rozsahu výzkumných dat byl pro výpočet korelačního koeficientu použit Spearmanův vzorec (Tabulka 5).

Tabulka 5: Hodnoty korelačního koeficientu zjištěné u jednotlivých hráčů

\begin{tabular}{|l|c|c|}
\hline Hráč & $\mathrm{r}_{\mathrm{X}, \mathrm{Y}}$ & $\alpha=0,05$ \\
\hline BT $(\mathrm{n}=12)$ & .16 & $\mathrm{~N}$ \\
\hline KM $(\mathrm{n}=10)$ & .16 & $\mathrm{~N}$ \\
\hline LD (n=14) & .03 & $\mathrm{~N}$ \\
\hline ML (n=11) & .37 & $\mathrm{~N}$ \\
\hline NM (n=14) & .22 & $\mathrm{~N}$ \\
\hline RM (n=9) & .42 & $\mathrm{~N}$ \\
\hline
\end{tabular}

Vysvětlivky: $r_{X, Y}-$ Spearmanův korelační koeficient, $N$ - korelace statisticky nevýznamná 
Výsledky korelační analýzy prezentované v Tabulce 5 prokazují u všech hráčů nízkou a statisticky nevýznamnou závislost $(\alpha=0,05)$ mezi úrovní motorických předpokladů a herní výkonností, hodnoty korelačních koeficienti̊ se pohybovaly v intervalu 0,03 až 0,42 (Anděl, 1985). Vzhledem ke komplexnosti faktorů ovlivňujících sportovní výkon v tenisu není nízká úroveň korelační závislosti překvapivá.

Protože však z řady výzkumů i z tenisové praxe je známý význam kondiční úrovně pro herní výkonnost v tenisu (Černošek et al., 2012; Reid et al., 2003; Schönborn, 2008), byla naším dalším cílem analýza úrovně motorických předpokladů jednotlivých hráčů. Střední hodnoty celkových výsledků hráčů ve sledovaném období jsou prezentovány v Tabulce 6.

Tabulka 6: Středni hodnoty skóre v testové baterii jednotlivých hráčů ve sledovaném období

\begin{tabular}{|c|c|c|c|c|c|c|}
\hline Hráč & BT & KM & LD & ML & NM & RM \\
\hline Medián & 8 & 9 & 9 & 7 & 10 & 10 \\
\hline
\end{tabular}

Z Tabulky 6 je zřejmé, že všichni sledovaní hráči prokazovali nadprůměrnou úroveň motorických předpokladů vzhledem ke střední hodnotě bodové škály (0-12 bodů, průměr 6 bodů). To koresponduje s vysokou herní výkonností jednotlivých hráčů prokázanou žebřričkovým umístěním.

\section{ZÁVĚRY}

Analýza výsledků dlouhodobého sledování úrovně motorických předpokladů šesti záměrně vybraných tenistů prokázala nízkou a statisticky nevýznamnou závislost mezi úrovní motorických předpokladů a herní výkonností, hodnoty korelačních koeficientů se pohybovaly v intervalu 0,03 až 0,42 .

Dále bylo zjištěno, že všichni sledovaní hráči prokazovali nadprůměrnou úroveň motorických předpokladů, střední hodnoty celkových výsledků hráčů ve sledovaném období se pohybovaly mezi 7 až 10 body (rozsah škály $0-12$ bodů, průměr 6 bodů). To koresponduje s vysokou herní výkonností jednotlivých hráčů prokázanou žebříčkovým umístěním a potvrzuje to předpoklad o významu kondiční přípravy v tenisu.

\section{LITERATURA}

Anděl, J. (1985). Matematická statistika. Praha, Czechia: Státní nakladatelství technické literatury. Crespo, M. \& McInerney, P. (2006). Talent Identification and Development in Tennis. Coaching \& Sport Science Review, 39. Retrieved December 10, 2013, from http://en.coaching.itftennis.com/news/116806.aspx

Černošek, M., Zháněl, J., Psalman, V. \& Zvonař, M. (2012). Diagnostika úrovně výkonnostních předpokladů tenistek (longitudinální studie). Studia sportiva, 6 (2), 19-37.

Deutscher Tennis Bund. (1996). Tennis-Lehrplan. Vol. 2. Unterricht \& Training. München, Deutschland: BLV. Dovalil, J., Choutka, M., Svoboda, B., Hošek, V., Perič, T., Potměšil, J. ... Bunc, V. (2009). Výkon a trénink ve sportu. Praha, Czechia: Olympia.

Grosser, M., \& Zintl, F. (1994). Training der konditionellen Fähigkeiten. Schorndorf, Deutschland: Hofmann. Grosser, M. \& Schönborn, R. (2008). Training im Kinder- und Jugendtennis. Aachen, Deutschland: Meyer \& Meyer.

Hendl, J., \& Blahuš, P. (2012). Metodologie výzkumné práce. Jak na to? Retrieved October, 19, 2012, from http://www.ftvs.cuni.cz/hendl/metodologie/index1.htm

Hohmann, A., Lames, M., \& Letzelter, M. (2010). Úvod do sportovního tréninku. (T. Studený, Trans.). Prostějov, Czechia: Sport a věda. (Originál vydán 2007).

Moravec, R., Kampmiller, T., Vanderka, M., \& Laczo, E. (2004). Teória a didaktika športu. Bratislava, Slovakia: Fakulta telesnej výchovy a športu.

Perič, T., \& Suchý, J. (2010). Identifikace sportovnich talenti̊. Praha, Czechia: Charles University.

Reid, M., Quinn, A., \& Crespo, M. (2003). Strength and Conditioning for Tennis. London, Great Britain: International Tennis Federation.

Schnabel, G., Harre, D., Krug, J., - Borde, A. (2003). Trainingswissenschaft. Berlin, Deutschland: Sportverlag. Schönborn, R. (2008). Optimální tenisový trénink. (T. Studený, Trans.). Olomouc, Czechia: doc. RNDr. Jiř́ Zháněl, Dr. (Originál vydán 2006).

Roth, K., \& Willimczik, K. (1999). Bewegungswissenschaft. Reinbek bei Hamburg, Deutschland: Rowohlt. Unierzyski, P. (2006). Foundations for Talent identification and Player Development Programmes. Coaching \& 
Sport Science Review, 39. Retrieved December, 10, 2013 from http://en.coaching.itftennis.com/news/116806. aspx

Wohlmann, R. (1996). Leistungsdiagnostik im Tennis. Ahrensburg, Deutschland: Czwalina.

Zháněl, J. Balaš, J., Trčka, D., \& Shejbal, J. (2000). Diagnostika výkonnostních předpokladů v tenise. Tenis, 11(3), 18-19.

Zháněl, J. (2005). Diagnostika výkonnostních předpokladi̊ ve sportu (a její praktická aplikace v tenise). Habilitační práce. Palacký University, Olomouc, Czechia.

Zháněl, J., Černošek, M., Martinovský, L., \& Agricola, A. (2008). Identifikace sportovních talentů v tenise - od talentu ke světové úrovni. In Identifikace sportovních talentů (pp. 16-20). Praha, Czechia: Charles University. 